\title{
A blessing with a curse: model minority ethnic students and the construction of educational success
}

Article

Accepted Version

Wong, B. (2015) A blessing with a curse: model minority ethnic students and the construction of educational success. Oxford Review of Education, 41 (6). pp. 730-746. ISSN 0305-4985 doi: https://doi.org/10.1080/03054985.2015.1117970 Available at https://centaur.reading.ac.uk/69981/

It is advisable to refer to the publisher's version if you intend to cite from the work. See Guidance on citing.

To link to this article DOI: http://dx.doi.org/10.1080/03054985.2015.1117970

Publisher: Taylor \& Francis

All outputs in CentAUR are protected by Intellectual Property Rights law, including copyright law. Copyright and IPR is retained by the creators or other copyright holders. Terms and conditions for use of this material are defined in the End User Agreement.

www.reading.ac.uk/centaur

\section{CentAUR}


Central Archive at the University of Reading

Reading's research outputs online 


\title{
A blessing with a curse: Model minority ethnic students and the construction of educational success
}

Billy Wong, School of Education, University of Roehampton, billy.wong@ roehampton.ac.uk

\begin{abstract}
While concerns around minority ethnic students and underachievement have attracted considerable attention in educational research, such as in England, few studies have examined those who excel, except as reference to justify the equity of the established system. This paper explores the educational success of British Chinese and Indian students, who are synonymously recognised as the model minority due to their tendency to achieve exceptional grades in national examinations. Data in this paper includes four discussion groups and 23 semi-structured interviews with British Chinese and Indian students (aged 11-14) and six teacher interviews. This study explores the social costs and benefits of the label of model minority and how these students attributed with such an identity construct and interpret educational success. Although high expectations by self and by others can positively contribute to the educational success of British Chinese and Indian students, inflated expectations can also generate a continuous sense of insecurity. Model minority students must contemplate the fear of failure and the potential damage they could inflict on the reputation of their family. Implications of the identity of model minority for students, teachers and policy are suggested.
\end{abstract}

\section{Introduction}

In England, educational attainment is stratified by gender, class and 'race'/ethnicity (DfE, 2014). Concerns about the achievement gap have focused on the underachievement of boys (e.g. Francis \& Skelton, 2005), working class students (e.g. Perry \& Francis, 2010) and particular minority ethnic groups, such as Black Caribbean students (Gillborn, 2008). Intersectional studies have also added complexity to our understanding of educational inequalities (e.g. Sveinsson, 2009, on White working class boys; Vincent, Rollock, Ball, \& Gillborn, 2012, on Black middle class families). While social justice studies within education have rightfully focused on underachieving students, particularly minority ethnic groups (Stevens \& Crozier, 2014), considerably less research have explored the education of academically successful students (e.g. Francis, Skelton, \& Read, 2012 on the popularity of high achieving students; Archer \& Francis, 2007, on high achieving British Chinese students). Aggregate statistics indicate that high attaining students in compulsory education are most likely to be girls, middle class and/or from British Chinese and Indian backgrounds (DfE, 2014). This article explores the educational experiences of these latter groups, who are sometimes referred to as the model minority in popular/media (Chua, 2013) and academic discourses (Gillborn, 2008) due to their tendency to attain exceptional grades in national examinations. This study investigates the social costs and benefits of the model minority stereotype and focuses on the ways in which British Chinese and Indian students construct, interpret and negotiate educational success.

The discourse of model minority is popularly used to acknowledge the educational/career success of minority ethnic groups. Lee $(2009$, p. 165) described it as 'a racist discourse, which categorizes, evaluates, ranks, and differentiates between groups'. In the US, these groups are typically associated with Asian Americans (Suzuki, 1977, 1989), particularly those with ancestral backgrounds from China, Korea and Japan. First mentioned 
by Peterson (1966) to describe the educational success of Japanese Americans, the term model minority was soon applied to all Asian American students, who are stereotyped as intelligent, studious and compliant (Lee, 2009). In public discourse, Asian Americans were elevated as a self-sufficient group who has integrated and 'succeeded' in American society, even though the statistics used to support these claims have been disputed (Suzuki, 2002). Although the model minority stereotype can support a self-fulfilling prophecy for some high achieving students (Lee, 2009), a body of literature have also cautioned about the potential dangers. These concerns can broadly be grouped into three themes: 1) justification of the existing educational system, 2) the heterogeneity within and between ethnic groups and 3) the hidden injuries of high attainment.

First, critics have argued that the model minority thesis, which emerged during the US Civil Rights Movement in the 1960s, was a political construction to defend the existing educational system (Lee, 2009; Suzuki, 2002). The apparent educational success of Asian American students provided evidence/confidence that the US schooling system does not discriminate against minority ethnic groups. In turn, the model minority stereotype infers a deficit model for those who, in comparison, 'underachieve' and counters arguments made by racially disadvantaged groups (e.g. African Americans) about educational discrimination (Yu, 2006).

Second, the widespread application of model minority onto Asian American students is problematic because the ethnic groups which make up this broad category include a range of cultures/ethnicities and attainment levels (Li, 2005; Pang, Han, \& Pang, 2011). Suzuki (2002) estimated that Asian Americans comprise of over thirty distinctive ethnic groups or subgroups, such as Hmong and Cambodians, who tend to underachieve (Ngo \& Lee, 2007). In other words, the model minority identity, commonly attributed to Asian Americans, can mask attainment variations within pan-ethnic groups.

Third, the model minority identity can dismiss students as individuals and present them with expected educational behaviours and performances, which can generate a range of pressures and 'hidden injuries' (Wong \& Halgin, 2006). There are concerns that the model minority label can cast a shadow over the needs and supports of these 'high achieving' students and ignore areas of inequality and deep-rooted disadvantages (Lee, 2009). The apparent success of Asian Americans (and those attributed as model minority more generally) may receive little or no support in terms of finance/bursary or targeted educational support programmes, such as affirmative action (Suzuki, 2002; Wong \& Halgin, 2006). Furthermore, subtle forms of racism and discrimination, such as verbal insults and requests for 'ethnic performances' (e.g. speak 'home' language) from teachers or peers, can be downplayed since these issues appear to have a limited effect on their educational outcomes (Archer \& Francis, 2007; Mau, 2014; Osajima, 1993).

Existing literature on the educational experiences of model minority is mostly based on the US experience. Comparatively fewer studies in the UK have explored the education of British Chinese and Indian students (e.g. Abbas, 2002a; Archer \& Francis, 2007; Bhopal, 2011; Mau 2014; Wong, 1992; Woodrow \& Sham, 2001), especially through the lens of the model minority stereotype.

The current study draws on postcolonial lens of identity as a way to understand the educational experiences and constructions of success among British Chinese and Indian students. Identity is conceptualised as a continuous process of social constructions, situated within matrices of power and structural relationships, such as gender, class and ethnicity (Butler, 1990; Hill Collins, 2000). Also informed by Hall (1990), identity is understood to be fluid, relational and can be thought of as a production that is always 'in process'. Hall explicates that people from minority ethnic backgrounds can be 'positioned and subject-ed in the dominant regimes of representation', which reflects a 'critical exercise of cultural power 
and normalisation' (p. 225). Identity locations such as gender, class and ethnicity can be governed through discourses, which constitute the norms and expectations of people located within these specific identity intersections. This study explores the extent to which minority ethnic students identify (or not) with the model minority stereotype as something typical or expected for 'people like us'. Identity provides a critical lens for understanding how British Chinese and Indian students perform and/or challenge the model minority stereotype. This study contributes to our understanding of the complex ways in which educational success can be negotiated through structural and social barriers and opportunities.

\section{The study}

As the highest achieving ethnic groups in England's national examinations (e.g. at GCSE ${ }^{1}$, see DfE, 2014), British Chinese and Indian students have been described as the model minority. This paper reports on an exploratory study which investigated the educational and career aspirations of minority ethnic young people (aged 11-14) in London, England. Data in the current paper included four discussion groups and 23 semi-structured interviews with British Chinese (seven boys, six girls) and Indian (four boys, six girls) students. The four discussion groups (two with Chinese-only students, two with Indian-only students) were made up of four to six participants (total of 19 students) and most Indian participants $(n=7)$ were also individually interviewed ${ }^{2}$. Six teachers (two females and four males, from Black African, White British and White European backgrounds) who taught the interviewed students were individually interviewed.

British Chinese and Indian students were recruited from three state co-educational ('Barton school', 'Cranberry school' and 'Everest school') and three Chinese complementary ('Lancang school', 'Yangtze school' and 'Hakka school') schools in London, and the latter schools were approached through personal contacts, as only two Chinese students had been recruited from state schools (out of the eventual 13) for individual interviews and discussion groups. As a general indication, the three state schools were ethnically diverse and about average in their respective local authority in terms of national examination results (e.g. GCSE). Chinese students recruited from complementary schools all attended state schools that were above average in terms of GCSE results. It is acknowledged that these Chinese students recruited from complementary schools (11 out of 13) may share collective (and even distinctive) views and experiences of education that may differ from Chinese students who have not attended Chinese complementary schools (e.g., their parents may be more conscious and actively engaged in their children's children and performance). Further research is merited.

Student interviews lasted 40 minutes on average and they were asked to talk about their (and their parents') expectations of their current and future education/grades, as well as their career aspirations. Interviews were audio recorded (with permission from students and their parents) and later transcribed verbatim, with student names anonymised. Teacher interviews lasted 45 minutes on average and focused on their experiences and expectations of teaching minority ethnic students, including of those who participated in this study. Discussion groups lasted between 30 and 70 minutes and students were encouraged to share and discuss the educational and career expectations of their parents/community, with the focus on similar or different family practices among specific ethnic groups.

Of the 23 students interviewed, the majority were considered as working class $(n=18)$ and five were considered as middle class ${ }^{3}$. All but one Chinese girl (Anita) were British born. Using government benchmarks of student grades expected from age 11 to 14 (DfE, 2010), most students interviewed in the study were above average achievers (17 out of 23 ), which mean they could share experiences and expectations (from self and others) that are 
comparable to the model minority stereotype. A smaller number of students were considered to be average $(n=3)$ and below average $(n=3)$ achievers, whose views could offer a different insight into the meaning of educational success for these supposedly 'underachieving' (i.e. not above average) model minority students. Students in discussion groups (but who were not individually interviewed) also reported above/average grades. Students' grades were selfreported but confirmed by teachers where possible. Most students reported similar grades across science, maths and English.

Interview transcripts were coded by emerging concepts and themes, with the author 'moving back and forth' between the data and analyses in an iterative process through which the dimensions of themes are refined through the comparison of data (Miles \& Huberman, 1994). Relevant themes from initial coding include: student educational expectations, student educational aspirations, parent educational expectations, parental educational aspirations and teacher/peer expectations. These themes were then theoretically analysed through the lens of identity to explore the performances, negotiations and resistances of students in relation to their constructions/interpretations of educational success. While model minority students, in this case Chinese and Indian students, may excel academically, the cost of their success is often overlooked and underexplored, particularly in the English/British context.

\section{Blessed with a climate of academic success}

Educational success may be accredited to individual effort/ability, but the learning environment - typically facilitated by the family and supported by the school - is also crucial to young people's educational prosperity (Crawford, Macmillan, \& Vignoles, 2014; EPPE, 2004). Unlike some minority ethnic groups (e.g. Black Caribbean) who have attracted negativity within British educational discourses (Gillborn, 2008), Chinese and Indian students generally draw praiseworthy compliments, particularly from teachers. Similar to Asian Americans in the US, British Chinese and Indian students, such as those in the current study, are generally characterised by their teachers as obedient, hardworking and quiet, with a strong traditional family work ethic/belief in education (Abbas, 2002b; Archer \& Francis, 2007; Youdell, 2006). The six teachers interviewed all articulated positive views/experiences of teaching British Chinese and Indian students. Mr Denzin (Cranberry school) believed that Indian students are typically high achievers 'because of their attitude to study ... very hardworking and focused'. He elaborated that they:

tend to respond to instructions, which is due to the notion of respect within the Asian/Indian communities. They inherit particular moral values on how to speak to adults, and so their behaviour and attitudes toward adults tend to be with a respectful manner.

Mr Denzin seems to have high regards for British Indian students, who are conceived to share the qualities of being respectful and responsive to teacher instructions. These qualities, along with a strong work ethic, appear to be recognised by teachers as fundamental to the educational success of British Indian students (Shain, 2003). Equally, all the teachers agreed that Chinese students generally achieve 'much better than average' (Ms Smith, Barton school), in line with the popular discourses of British Chinese students as academically successful (Archer \& Francis, 2007). Mr Tallman (Barton School) said that Chinese students excel academically because they are 'well behaved ... applied themselves to work essentially [and] their work ethic were strong'. He explained that Chinese students: 
tend towards the insular, like 'I'm here, I'm ready, I'm now ready to work', so, less chatty, but there is something about them, they do a lot more work behind the scene, so while they are lacking that chatting about [non-academic] things in the classroom, they're doing it at home.

According to Mr Tallman, Chinese students seem to consider the classroom a site only for academic learning, which may have contributed to their tendency of high educational outcomes. In fact, teachers may even be more willing (or accepting) for Chinese and Indian student to achieve, even if they are not high achievers. For example, Anita's (Chinese girl, Everest school) current grades would be considered below average (DfE, 2010) but her teacher, Ms Strauss, believed that her attainment dip is only temporary and can be rectified because Anita is a 'very hard working student'. Ms Strauss explained that because Anita has yet to develop 'a full command of English', she is currently prevented 'from accessing the knowledge that she needs to be able to do well'. Anita was not born in the UK and she reunited with her family in London three years prior to this study (when she was 9). While Anita can communicate using English, it is recognised that her current proficiency can be a limitation in her education. The fact that Ms Strauss offered an alternative explanation for Anita's low academic performance is in stark contrast to how teachers (including those in the current study) tend to justify the low/er achievements of other minority ethnic groups (e.g. Black Caribbean), which is often through deficit discourses (e.g. such as being lazy, challenging or have low aspirations) (Archer, 2003; Wright, 2010).

The model minority identity attributed to British Chinese and Indian students is not just reflective of the abovementioned student qualities or learning attitudes, but it is also supported/reinforced by what teachers expect from their family. Ms Strauss (Everest school) was convinced that Chinese parents 'would expect them [their children] to work very hard cos it's obvious when I'm teaching them [Chinese students] that they're very conscious of wanting to do well'. Such beliefs may help to expound her confidence in Anita's potential/future academic success. Similarly, Mr Annan (Barton school) said that Asian parents, particularly those with an Indian heritage, 'tend to be at the extreme ... they're pretty keen to see their kids do well'. Here, teachers have constructed or imagined Chinese and Indian parents to have very high expectations for their children that will ensure/facilitate educational success (Archer \& Francis, 2007). The seemingly positive constructions of British Chinese and Indian students from teachers can contribute towards a climate of high academic expectations for these model minority students (Yu, 2006).

More importantly, expectations of high grades are recognised and adopted by many British Chinese and Indian students. Below are two typical interview excerpts from Hins (Chinese boy, Lancang school) and Andy (Indian boy, Cranberry school), which illustrate that students generally appreciate and accept the high educational expectations of their parents, because it can also raise their own academic aspirations and identity as high achievers.

INT: Do they expect the good grades from you?

HINS: Closest to top as I can get.

INT: Would you say they have high expectations of you?

HINS: Yeah, it's quite high expectations but then it makes me work harder, so it's helpful I guess.

INT: Do you think your parents are similar to other Indian parents?

ANDY: Pretty much because they got high expectations, like getting high marks, which I hope I could achieve. 
INT: Do they expect you to get high marks?

ANDY: Yeah, because I've got kinda high marks all of these times, probably all over 80 or 70, out of 100 , I expect myself to get high marks as well.

Furthermore, aspirations to 'be the best' also emerged within some students' narrative of parental expectations, which refers to anticipations of top grades as an expected, rather than a desirable, educational outcome. Parents are generally constructed by Chinese and Indian students to have continuous aspirations for better and higher scores, perhaps to an extent whereby only the top/best grade is satisfactory. When asked if her parents are happy with her above average grades in school, Joanna (Chinese girl, Lancang school) said that 'they're not satisfied but they're not, not satisfied. They just like, try and aim higher next time, they are always saying that'.

Model minority students, who are typically Chinese and Indian students in England/the UK, reside within a high achieving educational environment that are strongly supported and manifested by the school and family. This means Chinese and Indian students are more likely to flourish without some of the social impediments that can negatively affect educational achievement, such as negative teacher stereotypes that seem to be more common for other minority ethnic groups (Strand, 2012). Instead, model minority students are encouraged to excel in education within school and family discourses, which promote a high achieving identity for Chinese and Indian students and situates what 'people like us' should be/do within education. Although clearly distinctive ethnic groups, it is noted that no obvious differences were observed between these 'blessings' for Chinese and Indian students. While such blessings may facilitate a climate of high educational attainment, the social cost of success can often be overlooked.

\section{The curse and cost of high expectations}

British Chinese and Indian students may have benefited from the model minority stereotype, although such an identity has been criticised in some US literature for its failure to acknowledge/recognise the social inequalities experienced by Asian Americans (Chou \& Feagin, 2010). This section discusses the difficulties associated with high expectations, particularly from teachers, parents and students' themselves. As discussed below, expectation of academic success demands continuous effort and vigilance - an identity which some (and particularly lower achieving) Chinese and Indian students struggle to sustain.

While generally praised as hardworking and obedient, Mr Tallman (Barton school) also warned that Chinese students can be too quiet as they tend to be 'socially isolated in the classroom, by choice, it's like, I'm here to work'. Similarly, Ms Smith (Barton school) said that Chinese students:

don't really ask questions either, it's almost impossible to get them put their hands up to ask questions ... it's very hard to get them actively engaged in a conversation about what we're doing because they want me to tell them what the answer is and ... leave them to get on with it.

Self-discipline and dedication to individual hard work may be key ingredients for high achievement, but these characteristics can also deprive students from other, equally valuable, learning opportunities, particularly through social interaction and communication. Here, being quiet seems to be a pathologised feature of high achieving Chinese students. The pressure to succeed, particularly from the home, is also acknowledged by teachers. Not only did Ms Smith (Barton school) recognise that Chinese and Indian parents do not expect their 
children 'to fail' in school, she was convinced that for these parents, their children 'must be good at something', such as the 'piano, in maths or PE, singing or something, something that they must be very, very, good at and everything else they must be at an acceptable level'. In other words, aside from a good set of grades across subjects, model minority students may also be expected (from parents and/or teachers) to excel in at least one discipline. Such perceptions may reflect wider stereotypes of British Chinese or Indian students in that they should generally be good at something. Ms Smith was philosophical about the high expectations asserted by Chinese parents as she discussed the potential implications for these students who fail to achieve academic success:

I think it's a matter of shame. The child gets to feel ashamed, that they somewhat let the family down in some respect, it's like a big all-in [family] involvement, which can be a very good support base, to give children motivation and things like that but then it can also be, a very hard thing for a child to be put in that situation, they learn to act in a certain way.

Similarly, Mr Tallman (Barton school) believed that Indian parents would 'put a lot of pressure on their kids' if he voiced any concerns about their performances or grades in class, which could result in 'extra tuition' and additional support from 'older siblings or cousins, relatives and uncles'. Mr Tallman also recognised that 'some kids thrive on it but other kids cannot cope'.

Teachers generally have positive views of model minority students (and their families) as fundamentally good, hardworking and high achieving. Yet, their problem-free constructions could also limit teacher-parent interactions, as these seem more common among 'problematic' students. Mr Cartier (Barton school) explained that because Chinese students are generally unproblematic (i.e. no concerns with classroom behaviours or academic performances), he 'didn't really have a reason to speak to their parents'. Similarly, disobediences from Chinese and Indian students were considered 'rare' by Mr Annan (Barton school), who also seem to downplay the severity of these misconducts when it happens. He said that the misbehaviours of Chinese and Indian students tend 'not to disrupt anybody else in the process', whereas other mischievous students (i.e. those from other ethnic backgrounds) may 'just get out of their chairs and start wander around or shouting aloud'. Indeed, even low/er achieving Chinese or Indian students are expected to, eventually, succeed (e.g. see Ms Strauss' evaluation of Anita earlier). Hence, teachers may have fewer communications with model minority parents because their children are typically stereotyped as unproblematic and as such they may devote less attention or support (e.g. in the classroom) to these apparently (or assumed) successful students (Yu, 2006).

For many Chinese and Indian students, expectations of continuous success can exert fears of being 'never good enough'. According to Dee (Chinese boy, Lancang school), his father was 'not very fond of my scores of getting 70\%'. Although Dee believed that 'it's a good score for me, I think anything above 50, well, 60, is a good score', he acknowledged that his parents hoped for ' $100 \%$ because without the top grades, you're going down in this society ... they say get the top grade for everything'. While similar views were expressed by other students in the study, few students elaborated on the potential consequences of failure. When asked about how his parents would react if he did not achieve the top grade, Dee speculated that 'they're probably give me a grunt or give me a shout for it and probably a kicking in the arse'. A more extreme penalty was elicited by Donald (Chinese boy, Hakka school), who claimed that 'if you don't do well, they'll hit you with a stick, they will get angry'. Although the practice, severity and nature of 'physical punishment' should be read with caution, what seems clear is that lower-than-expected grades, however interpreted, is not acceptable for 
some Chinese and Indian parents. Model minority students may reside in a home environment with limited tolerance for academic underperformance.

Zhou (2009) found in the context of Asian American communities that individual success (such as admission to Ivy League universities or high status professions) can often entail his/her family members gaining 'face' (i.e. respect) within their local communities. In a discussion group with Indian girls, the potential risk of poor academic performance to the 'face' of the family was insinuated:

SAMANTHA: But you know my dad yeah, he pushes us too much BECKY: Yeah

SAMANTHA: He thinks I don't know anything and he starts going like mad, like tuitions, so much tuitions and it's like so much

BECKY: Yeah they expect too much out of us and we have to focus [on education] all the time

JENNY: That's because they have a crap job and they want their children to have a good job

SAMANTHA: Yeah like people judge them on how their kids are if they're smart and stuff

In the above exert, the girls' spoke of their shared high expectations from family members, which involved excessive tuitions and study. Samantha, at the end, also raised the link between their own academic performances and the reputation of their family. Indeed, failure to achieve parental expectations could lead to family humiliation, as explicated in a group discussion with Indian boys:

RAMOS: And also your parents might be like, 'I'm gonna make my son become a doctor or lawyer', and when you don't, like your son doesn't become that they become something like a rubbish cleaner or that, then that'd be like a huge-

ANDY: Shame-

RAMOS: Disappointment for them and a big embarrassment cos they will like, say to everyone, 'I'll make my son become this and that' and they don't become that.

As inferred by Ramos and Andy, family 'face' can propel (and pressurise) students to achieve high grades because educational/occupational failure (or success) is not just an issue for students themselves but also represents the 'face' (and dignity) of the family. Children can bring 'big embarrassment', 'shame' and 'disappointment' to their families should they fail to accomplish what their parents had expected them (and maybe advertised to others) to achieve. Some students also believed that their parents are stricter towards their education than those of their peers, or more specifically, parents of their White English/British peers:

I think, there's a difference between, I'm not being racist, Asian and White people, erm, because White parents ... want their child to be happy by doing whatever they want, but Asians want us to aim high ... they have high expectations for their children. (Ramos, Indian boy, Cranberry School)

I reckon Chinese parents like push their child more and more strict, whereas people over here, people over here kinda, like, some doesn't really care, like, 'oh, she got a D, OK'. (Joanna, Chinese girl, Yangtze School) 
According to Ramos and Joanna, Indian and Chinese parents are more goal-oriented than White parents, which they have constructed through a discourse of 'the accomplishment of natural growth' (Lareau, 2003) - a working class parenting strategy that promotes children's own interests/decisions (see also Sveinsson, 2009). Model minority students seem to have constructed their own parents as stricter and with higher expectations than other parents. In a related vein, the career aspirations mentioned by British Chinese and Indian students appear to be narrow, predominantly in the fields of finance, law (for Chinese) and medicine (for Indian). As elaborated elsewhere (see Wong, 2015a), these careers are more identifiable and are perceived to have good economic returns and social status, and thus highly favoured by model minority parents. For example, Vincy (Indian girl, Cranberry school) said that within her local community, many parents expect their children to be doctors, because it is 'a common job' for 'people like us'.

Model minority students are typically high achievers, but not all British Chinese and Indian students attain highly, even though they share the ethnicities associated with the model minority stereotype in the UK. Few students in the current study were considered to be average $(n=3)$ or below average $(n=3)$ in terms of grades (rather than above average, $n=17)$, but it appear that their freedom (or lack of) to choose their future pathways may be especially limited. For instance, Anita (Chinese girl, Everest school) wanted to be a dancer, but her aspiration was dismissed by her parents as 'rubbish' because it was considered 'not good enough' in terms of 'money and respect'. Indeed, Anita bemoaned that her parents expect her to study finance at 'the prestigious Oxford University', even though Anita herself wanted to attend a performing arts school. Similarly, expectations of success, particularly among low/er achievers, can generate additional burden and self-doubt. According to Slifer (Indian boy, Barton school), his mother 'said get good levels in all of the subjects, every single one ... but I'm like, how am I meant to do that? I don't even know if I get pass GCSE'. The pressure to achieve has even prompted Harry (Chinese boy, Everest School) to question his own Chinese background. As a below average achiever, Harry distanced his association with the model minority stereotype by asserting that he is actually 'Malaysian Chinese', and thus the popular expectation of academic success for British Chinese do not completely apply to him. Yet, Harry recalled how he was 'upset and slightly angry' when he was once awarded a high grade, only for his peers to downplay his effort by saying 'you're Chinese so that's normal for you'. Harry said that he tried 'not to care what other people say' but his Chinese ethnicity (and subsequent associations with the model minority identity) appears to be a curse rather than blessing.

\section{Discussion and conclusion}

The model minority identity, typified onto Chinese and Indian students in the UK, can offer unique opportunities unavailable to other ethnic groups. However, the stereotype, which constructs educational success as expected, can also be a curse for British Chinese and Indian students. Consistent with existing literature (Archer \& Francis, 2007; Youdell, 2006), Chinese and Indian students are typically constructed by teachers in this study as diligent, solemn and pragmatic toward their education. They are considered to be quiet and their lack of vocal participation in the classroom may be encapsulated by the motto 'I'm here to work'. Many Chinese and Indian students also seem to recognise and appreciate these high expectations of them, particularly from the family, as a way to encourage and promote their own academic aspirations and expectations. As such, they appear to be blessed with a high achieving student identity, which seems to be readily available for (or expected of) them. Yet, the model minority stereotype is not all positive. British Chinese and Indian students are not constructed by teachers as 'ideal' or 'natural' - a student identity which may be reserved for 
White middle class students, particularly boys (Francis \& Skelton, 2005). Instead, the academic success of model minority students seems to be interpreted by teachers as hardearned and sacrificial (Yamamoto \& Li, 2012). The model minority stereotype is argued to be a blessing with a curse because it can work in the favour of Chinese and Indian students in some circumstances, but can also generate uneasiness and anxiety due to excessive expectations.

British Chinese and Indian students in the current study expressed career aspirations toward professional occupations, although more specifically in the fields of medicine, finance and law (Archer \& Francis 2007; Springate, Harland, Lord, \& Wilkin, 2008). The tendency for Indian students to express medical career aspirations may reflect particular family/community values, which seem to posit these careers as highly desirable or even expected (Wong, 2012, 2015b). Indeed, HESA (2014) data revealed that UK domiciled Indian students represented $10.6 \%$ of all medicine and dentistry undergraduate students in 2013, despite being $3.3 \%$ of the undergraduate population. Similarly, British Chinese students constituted $2.4 \%$ of those who study mathematical sciences (and $2.2 \%$ for medicine and dentistry), even though they make up just $0.8 \%$ of undergraduates (ibid.). While Chinese and Indian students are also proportionally overrepresented in law and business degrees, they are poorly represented in many other areas such as historical/philosophical studies, language, education and creative arts/design. These official data are coherent with the ambitions of Chinese and Indian young people in the present study, in that their career aspirations tend toward a narrow list of high status professions. Although the appeal of 'known' and 'safe' career routes may provide students (and their families) a sense of security in that certain professions have already been achieved by 'people like us' (Archer, DeWitt, \& Wong, 2014), such a strategy can also deprive students of the freedom to choose and to develop/explore other areas of interest. Narrowed career paths can also be 'risky', particularly if that particular field experiences economic, political or social instability (e.g. government spending cut or the privatisation of the National Health Service).

The participants in the current study noted that failure to achieve high/anticipated grades can endanger the reputation of the family, which, as reported in Ying et al. (2001), can increase the pressures and emotional struggles of these model minority students to live up to particular family expectations. These concerns are vivid in British Chinese and Indian students' narratives, particularly through their worries of being 'never good enough' or fears of 'embarrassing' their family. As expectations of high grades become customary, Chinese and Indian students may receive fewer recognition or praise (e.g. from teachers or parents) for their achievements, which can be particularly stressful for low/er achievers as their accomplishments may be downplayed. Furthermore, these high expectations may even prompt students, especially low/er achievers (e.g. Harry), to question their own ethnicity - a social identity that is intricately linked to the model minority stereotype in the UK. Although less apparent among students in the current study, existing studies have also raised concerns about covert, or subtle, forms of racism that experienced by highly successful minority ethnic students, such as the British Chinese (Archer \& Francis, 2007; Mau, 2014). However, these forms of racism can be overlooked by teachers and even students themselves because model minority students are academically successful. As such, the high attainment of model minority students can often overshadow the price, burden or 'hidden injuries' of academic success (Li, 2005). Similar stories are also reported by Pomerantz \& Raby (2011) and Ringrose (2007) in the broader context of high achieving girls, where some girls stressed about the continuous pressure (from self and others) to perform, prove and excel in every aspect of their education.

The positive views teachers seem to have of Chinese and Indian students can potentially benefit those who are low/er achieving, in that their poor attainment are seen to be 
temporary, rather than as irreversible, as in the case of most other minority ethnic groups (Crozier \& Davies, 2008; Gillborn, 2008). As demonstrated from the example of Ms Strauss and her evaluation of Anita's educational trajectory, the teacher has belief/expectation that the student's grades will eventually improve. While seemingly positive (presumably for Anita), such views may also underlie a wider concern around the support that is available to model minority students (Li, 2005). General optimism from teachers about the progress of Chinese and Indian students could limit the time and resources dedicated to support their education since they are typically considered as unproblematic (Yu, 2006). Yet, the teachers also noted that British Chinese and Indian students, particularly the former, can be socially isolated in the classroom due to their commitment to study. This is a concern especially since Hsin \& Xie (2014) have found that high achieving Asian Americans report lower self-esteem and fewer social interactions with peers than other students. Further research is merited in the context of model minority students in the UK.

In other words, the academic success of the majority (of British Chinese and Indian students) can concurrently create a very difficult educational climate for the minority (of British Chinese and Indian students) who are not high achievers. These students may be atypical of their ethnicity but their needs may be dwarfed by amiable statistics which present Chinese and Indian students as the highest attaining ethnic groups in national examinations. For example, around $75 \%$ of British Chinese and Indian students achieved the benchmark grades of $5 \mathrm{~A}^{*}-\mathrm{C}$ grades at GCSE (DfE, 2014). Yet, little if any policy or research attention is given to the unsuccessful $25 \%$. Some may rightfully state that Chinese and Indian students, on the whole, still outperform every other ethnic group, but the moral and political question is how 'acceptable' is it that one in four Chinese or Indian students fail to achieve the benchmark grades? Within ethnic groups, can the success of the majority justify the apparent negligence of the minority? Here, the problem with the identity of model minority is that such label is typically attributed to specific groups, rather than to individuals, and thus the needs of individuals are neglected.

This study has only noted minor, perhaps trivial, differences between the ways in which British Chinese and Indian students experience and construct educational success. While both groups were typically regarded as high achievers, the teachers seem to have focused on the quiet and obedient characteristics of Chinese students, while Indian students were mostly discussed in terms of community values and expectations. While most have voiced concerns about the potential damage they can cause to their family in terms of 'face' or reputation due to low attainment, only a few Chinese students spoke of actual punishment from their parents due to 'poor' academic results. All of these variations, although minor, require further research. One area of difference between these two groups is their geographical residence, which may explain the different roles of community for model minority students in the UK. The British Chinese population are generally dispersed throughout the country, while the British Indians are more likely to live in ethnic enclaves, where local community networks/values are often formed (ONS, 2011).

This study calls for concerted efforts to diversify the thinkable (and 'acceptable') career pathways of (model minority) students, beyond the few, highly exclusive professions. For example, careers education may need to specifically target Chinese and Indian students to actively explore with them the wider range of career pathways aside from the fields of medicine, law and finance. In practice, schools and teachers should also involve family and/or community members as part of the overall strategy, since the choices of minority ethnic students seem to be heavily shaped or 'governed' by these key adults (Basit, 2012). As such, schools may develop career workshops for model minority parents with the aim to broaden the range of 'acceptable' careers they may have for their children. Indeed, a widened career view (from parents) will be particularly beneficial to low/er achievers from British 
Chinese and Indian backgrounds, who may gain more familial/community support to pursue their own careers, rather than be expected to fulfil/enter particular educational and career pathways. This study contributes to our growing knowledge-base of the education of 'successful' minority ethnic groups, particularly in the UK context, as well as problematising the identity of model minority as a 'blessed' but also 'cursed' label. Findings from this study will serve to remind policymakers, practitioners and researchers of the need to consider the educational needs and concerns of high achievers, particularly from minority ethnic backgrounds.

\section{References}

Abbas, T. (2002a). The home and the school in the educational achievements of South Asians. Race Ethnicity and Education, 5, 291-316.

Abbas, T. (2002b). Teacher perceptions of South Asians in education. Oxford Review of Education, 28, 447-471.

Archer, L. (2003). Race, masculinity and schooling: Muslim boys and education. Berkshire: Open University Press.

Archer, L., \& Francis, B. 2007. Understanding Minority Ethnic Achievement: The role of race, class, gender and 'success'. London: Routledge.

Archer, L., DeWitt, J., \& Wong, B. (2014). Spheres of influence: what shapes young people's aspirations at age 12/13 and what are the implications for education policy? Journal of Education Policy, 29, 58-85.

Basit, T. N. (2012). 'My parents have stressed that since I was a kid': Young minority ethnic British citizens and the phenomenon of aspirational capital. Education, Citizenship and Social Justice, 7, 129-143.

Bhopal, K. (2011). 'We tend to stick together and mostly we stick to our own kind': British Indian women and support networks at university. Gender and Education, 23, 519-534.

Butler, J. (1990). Gender trouble. New York: Routledge.

Chou, R. S. \& Feagin, J. R. (2010). The Myth of the Model Minority: Asian Americans Facing Racism. Boulder, CO: Paradigm.

Chua, A. (2011). Battle Hymn of the Tiger Mother. London: Penguin Books.

Crawford, C., Macmillan, L., \& Vignoles, A. (2014). Progress made by high-attaining children from disadvantaged backgrounds. London: Social Mobility and Child Poverty Commission.

Crozier, G., \& Davies, J. (2008). 'The trouble is they don't mix': Self-segregation or enforced exclusion? Race, Ethnicity and Education, 11, 285-301.

DfE. (2010). National Curriculum Assessments at Key Stage 2 \& 3 in England, 2009/10 (Provisional). SFR 23/2010. London: Department for Education.

DfE. (2014). GCSE and equivalent results by England, 2012/13. SFR05/2014. London: Department for Education.

EPPE. (2004). The Effective Provision of Pre-School Education (EPPE) Project: Final Report. SSU/FR/2004/01. London: DfES.

Francis, B., \& Skelton, C. (2005). Reassessing gender and achievement: Questioning contemporary key debates. London: Routledge.

Francis, B., Skelton, C., \& Read, B. (2012).The Identities and Practices of High Achieving Pupils. London: Continuum.

Hall, S. (1990). Cultural identity and diaspora, in: J. Rutherford (Ed) Identity: Community, Culture, Difference. London: Lawrence \& Wishart, 222-237. 
HESA. (2014). Table J - UK domiciled undergraduate students of known ethnicity by subject area(\#1) and ethnicity 2012/13. Accessed $14^{\text {th }}$ November 2014. URL:

https://www.hesa.ac.uk/images/stories/hesa/Pubs_Intro_Graphics/STUDENT_1213/studen t_1213_table_J.xlsx

Hill Collins, P. (2000). Black feminist thought: Knowledge, consciousness and the politics of empowerment. 2nd Edition. New York: Routledge.

Hsin, A., \& Xie, Y. (2014). Explaining Asian Americans' academic advantage over Whites. Proceedings of the National Academy of Sciences of the United States of America (PNAS). DOI: $10.1073 /$ pnas.1406402111

Lareau, A. (2003). Unequal childhood. Berkeley: University of California Press.

Lee, S. J. (2006). Additional complexities: Social class, ethnicity, generation, and gender in Asian American student experiences. Race Ethnicity and Education, 9, 17-28.

Lee, S. J. (2009). Unraveling the" model minority" stereotype: Listening to Asian American youth. 2nd edition. New York, NY: Teacher College Press.

Li, G. (2005). Other people's success: Impact of the 'model minority' myth on underachieving Asian students in North America. KEDI Journal of Education Policy, 2, 69-86.

Mau, A. (2014). Beyond Kung Fu and Takeaway: Negotiation of British Chinese Identities in Schools, in: R. Race and V. Lander (Eds) Advancing Race and Ethnicity within Education. Basingstoke: Palgrave Macmillan, 111-127.

Miles, M. B., \& Huberman, A. M. (1994). Qualitative data analysis. 2nd Edition. Thousand Oaks, CA: SAGE.

Ngo, B., \& Lee, S. (2007) Complicating the Image of Model Minority Success: A Review of Southeast Asian American Education. Review of educational research, 77, 415-453

ONS. (2011). Population Estimates by Ethnic Group 2002 - 2009. Statistical Bulletin. London: Office for National Statistics.

Osajima, K. (1993). The hidden injuries of race, in: L. A. Revilla, G. M. Nomura, S. Wong, \& S. Hune. (Eds) Bearing dreams, shaping visions. Pullman: Washington State University Press, 81-91.

Pang, V. O., Han, P, P., \& Pang, J. M. (2011). Asian American and Pacific Islander Students Equity and the Achievement Gap. Educational Researcher, 40, 378-389.

Perry, E, \& Francis, B. (2010). The social class gap for educational achievement: a review of the literature. London: RSA.

Peterson, W. (1966). Success story: Japanese American style. New York Times Magazine, Section 6, pp. 20-43. January $9^{\text {th }} 1966$.

Pomerantz, S., \& Raby, R. (2011). 'Oh, she's so smart': girls' complex engagements with post/feminist narratives of academic success. Gender and Education, 23, 549-564.

Ringrose, J. (2007). Successful girls? Complicating post-feminist, neoliberal discourses of educational achievement and gender equality. Gender and Education, 19, 471-489.

Strand, S. (2012). The White British-Black Caribbean achievement gap: Tests, tiers and teacher expectations. British Educational Research Journal, 38, 75-101.

Shain, F. (2003). The schooling and identity of Asian girls. Staffordshire: Trentham Books.

Stevens, P. A., \& Crozier, G. (2014). England, in: P. A. J. Stevens \& A. G. Dworkin. (Eds) The Palgrave Handbook of Race and Ethnic Inequalities in Education. Basingstoke: Palgrave Macmillan, 259-307.

Springate, I., Harland, J., Lord, P., \& Wilkin, A. (2008). Why choose physics and chemistry? The influences on physics and chemistry subject choices of BME students. London: Institute of Physics.

Suzuki, B. H. (1977). Education and the socialization of Asian Americans: A revisionist analysis of the model minority thesis. Amerasia Journal, 4, 23-51. 
Suzuki, B. H. (1989). Asian Americans as the 'Model Minority': Outdoing Whites? Or Media Hype? Change: The Magazine of Higher Learning, 21, 13-19.

Suzuki, B. H. (2002). Revisiting the Model Minority Stereotype: Implications for Student Affairs. Practice and Higher Education, 97, 21-32.

Sveinsson, K. P. (2009). Who cares about the white working class? London: Runnymede Trust.

Vincent, C., Rollock, N., Ball, S., \& Gillborn, D. (2012). Being strategic, being watchful, being determined: Black middle class parents and schooling. British Journal of Sociology of Education, 33, 337-354.

Wright, C. (2010). Othering difference: framing identities and representation in black children's schooling in the British context. Irish Educational Studies, 29, 305-320.

Wong, B. (2012). Identifying with science: A case study of two 13 year-old British Asian 'high achieving working class' schoolgirls. International Journal of Science Education, 34(1), 43-65.

Wong, B. (2015a). Careers 'from' but not 'in' science: Why aspirations to be a scientist are challenging for minority ethnic students? Journal of Research in Science Teaching. DOI: $10.1002 /$ tea. 21231

Wong, B. (2015b). Minority Ethnic Students and Science Participation: a Qualitative Mapping of Achievement, Aspiration, Interest and Capital. Research in Science Education. DOI: 10.1007/s11165-015-9466-x

Wong, L.Y.F. (1992). Education of Chinese children in Britain and the USA. Clevedon: Multilingual Matters.

Wong, F., \& Halgin, R. (2006). The "Model Minority": Bane or Blessing for Asian Americans. Journal of Multicultural Counseling and Development, 34, 38-49.

Woodrow, D., \& Sham, S. (2001). Chinese Pupils and Their Learning Preferences. Race, Ethnicity and Education, 4, 377-394.

Yamamoto, Y., \& Li, J. (2012). Quiet in the eye of the beholder: Teacher perceptions of Asian immigrant children, in: C. Garcia Coll. (Ed) The impact of immigration on children's development. Basel: Karger, 1-17.

Ying, Y. W., Lee, P. A., Tsai, J. L., Hung, Y., Lin, M., \& Wan, C. T. (2001). Asian American college students as model minorities: An examination of their overall competence. Cultural Diversity and Ethnic Minority Psychology, 7, 59-74.

Youdell, D. (2006). Impossible bodies, impossible selves: Exclusions and student subjectivities. Dordrecht: Springer.

Yu, T. (2006). Challenging the Politics of the 'Model Minority' Stereotype: A Case for Educational Equality. Equity \& Excellence in Education, 39, 325-333.

\footnotetext{
${ }^{1}$ General Certificate of Secondary Education (GCSE) is an academic qualification generally taken by students aged 14-16 in England, Wales and Northern Ireland.

2 Chinese students in focus groups did not participate in individual interviews due to practical constraints.

3 This included two Chinese girls, one Chinese boy and two Indian boys. Middle class students are considered to have at least one university-educated parent in a professional/managerial job (NS-SEC Class 1 or 2). Working class students have parent(s) with education up to college level and with manual or low-skilled occupations (NS-SEC Class 3).
} 